\title{
The Secondary Sex Ratio at Birth Was Depressed in Quebec by the Sovereignty Referendums
}

\author{
Victor Grech, MD, PhD (Lond), PhD (Malta), FRCPCH, FRCP(UK), DCH
}

Associate Professor of Paediatrics, University of Malta, Msida, Malta

\section{Abstract}

Introduction: Globally, male live births exceed female live births by approximately $3 \%$. The secondary sex ratio is conventionally expressed as male births divided by total live births (M/T). Many factors have been implicated as influencing this ratio, such as stress (including non-violent political events) and toxins, both of which reduce it. The Quebec government twice proposed referendums to its populace advising sovereignty. This study was carried out in order to ascertain whether the referendums had any effect on the M/T ratio in Quebec and in Canada as a whole.

Methods: Annual births in Quebec and Canada were compared for the index (referendum) years 1980 and 1995 versus the sum of the preceding and following five year periods, for each event. The monthly M/T ratio for Quebec before and after the 1995 referendum was also calculated.

Results: This review covered 8099600 live births. In Quebec, the $M / T$ ratio was lower in the two referendum years than in the preceding and following five year periods, and was significantly lower after the 1995 referendum $(P=0.04)$. No significant changes were noted for Canada as a whole. Monthly calculations for Quebec showed a decline in the $\mathrm{M} / \mathrm{T}$ ratio three months after the 1995 referendum $(P=0.035)$, followed by a rapid recovery $(P=0.001)$.

Conclusion: The second Quebec referendum on sovereignty in 1995 had a higher voter turnout than the 1980 referendum and was more closely run. Reductions in the $\mathrm{M} / \mathrm{T}$ ratio have been noted in association with stressful population events, including non-violent political activities. This may have been the case in Quebec, where the $M / T$ ratio declined in association with two referendums that proposed sovereignty, possibly due to the stress engendered by these events and the potential outcomes.

\section{Résumé}

Introduction : À l'échelle mondiale, le nombre de naissances vivantes de garçons dépasse le nombre de naissances vivantes de filles dans une proportion d'environ $3 \%$. Le taux de masculinité des naissances est classiquement obtenu en divisant le nombre de naissances de garçons par le nombre total des naissances vivantes (taux $M / T$ ). De nombreux facteurs exerçant un effet sur ce taux ont été identifiés, comme le stress (y compris celui qui est associé aux événements politiques non violents) et les toxines (ces deux facteurs entraînant une baisse du taux en question). À deux reprises, le gouvernement du Québec a proposé un référendum sur la souveraineté à sa population. Cette étude avait pour but de déterminer si ces référendums avaient exercé quelque effet que ce soit sur le taux M/T au Québec et dans l'ensemble du Canada.

Méthodes : Les naissances annuelles au Québec et au Canada au cours des années probantes (référendums de 1980 et de 1995) ont été comparées, dans chaque cas, à la somme des naissances annuelles des cinq années précédentes et des cinq années suivantes. Le taux M/T mensuel pour le Québec avant et après le référendum de 1995 a également été calculé.

Résultats : Cette analyse a couvert 8099600 naissances vivantes. Au Québec, le taux M/T a été plus faible au cours des deux années référendaires qu'au cours des quinquennats précédents et suivants; il a été considérablement amoindri à la suite du référendum de $1995(P=0,04)$. Aucune modification significative n'a été constatée dans l'ensemble du Canada. Pour ce qui est du Québec, les calculs mensuels ont indiqué un déclin du taux $M / T$ trois mois à la suite du référendum de $1995(P=0,035)$, le tout ayant été suivi d'une récupération rapide $(P=0,001)$.

Conclusion : Un plus grand taux de participation a été constaté dans le cadre du référendum québécois sur la souveraineté de 1995, par comparaison avec le référendum de 1980; les résultats ont également été plus serrés en 1995 qu'en 1980. Des baisses du taux $M / T$ ont été constatées en association avec des événements populationnels stressants, y compris des activités politiques non violentes. C'est ce qui a pu se produire au Québec, où les taux $\mathrm{M} / \mathrm{T}$ ont connu un déclin en association avec les deux référendums sur la souveraineté, et ce, peut-être en raison du stress engendré par ces événements et leurs conséquences potentielles.
Key Words: Canada, Quebec, birth rate, birth trends, infant, newborn, sex ratio, politics

Competing Interests: None declared.

Received on October 20, 2014

Accepted on December 9, 2014 


\section{INTRODUCTION}

$\mathrm{M}$ ale live births narrowly exceed female live births globally by approximately 3\%. ${ }^{1}$ The secondary sex ratio is conventionally expressed as the number of male births divided by the number of total births, and is referred to as the $\mathrm{M} / \mathrm{T}$ ratio. The reasons for the discrepancy in the sex distribution at birth are uncertain, but a large number of factors have been implicated as influencing this ratio. ${ }^{1,2}$

Factors that reduce the $\mathrm{M} / \mathrm{T}$ ratio (i.e., lead to relatively fewer male births) include toxins, ${ }^{1,2}$ privation and famine, ${ }^{3}$ natural calamities, ${ }^{4}$ short wars, ${ }^{5}$ and elements that induce stress in populations. Examples of the latter include political events such as terrorist attacks, as evidenced in New York after the attacks of September 11, 2001. ${ }^{6}$ The mechanism appears to be the spontaneous induction of intrauterine fetal death, which affects male fetuses more than female fetuses. ${ }^{7}$

These effects are noted even in extrauterine pregnancies; when such events lead to delivery of a live baby, there is a reduction in the proportion of males (to 37.5\%). ${ }^{8}$ This may be due to the excessive loss of male fetuses, which are physiologically more vulnerable in the unusual and presumably more hostile extrauterine environment. The effects of stress on the $\mathrm{M} / \mathrm{T}$ ratio may be quite powerful even in populations that are not directly threatened, as witnessed in California after the September 11 attacks (where the $\mathrm{M} / \mathrm{T}$ ratio also fell).

Non-violent political events have also occasionally been shown to lower the $\mathrm{M} / \mathrm{T}$ ratio. For example, the $\mathrm{M} / \mathrm{T}$ ratio in Cuba dipped sharply in three different years in response to legislation enacted in the United States. ${ }^{10}$ Democratic Maltese parliamentary elections have also been shown to lower the $\mathrm{M} / \mathrm{T}$ ratio in that country. ${ }^{11}$

Debates in Quebec advocating independence have loomed large in the province's politics. Indeed, the Quebec sovereignty movement comprises not only political aspects, but also an ideology of values, concepts, and ideas that champions sovereignty. ${ }^{12}$

Parti Québécois governments held referendums on the issue of secession from Canada in 1980 and 1995. Both had close outcomes and resulted in defeat of the proposal by a small margin, especially the second referendum on October $30,1995 .^{12}$ This study was carried out in order to ascertain whether the referendums had any effect on the $\mathrm{M} / \mathrm{T}$ ratio in Quebec and in Canada as a whole.

\section{METHODS}

Data for annual births in Quebec and annual births in Canada were obtained from the website of Statistics
Canada (StatsCan) for the period 1971-72 to 2013-14. Annual data were available for one-year periods ranging from July 1 to June 30 of the following year. ${ }^{13}$ Data for annual stillbirths in Canada and in Quebec were also obtained from Statistics Canada, and these were available up to 1991. Data were obtained for fetal deaths (20 weeks or more of gestation) and late fetal deaths ( 28 weeks or more of gestation).

Data analysis and charting was carried out using Microsoft Excel (Microsoft Corp., Redmond WA). The quadratic equations of Fleiss were used for the calculation of $95 \%$ confidence intervals. ${ }^{14}$ Chi-square tests were applied using the Bio-Med-Stat Excel add-in for contingency tables. ${ }^{15}$

Comparisons were made for the index (referendum) years versus the sum of the preceding and following five-year periods. Short periods were chosen because it is known that the $\mathrm{M} / \mathrm{T}$ ratio demonstrates temporal cyclic changes. ${ }^{16}$ Thus, the referendum year 1980-1981 was compared with the totals for 1975-1976 to 1978-1979 and 1981-1982 to 1985-1986, and the referendum year 1995-96 was compared with the totals for 1990-1991 to 1993-1994 and 1996-1997 to 2000-2001.

Monthly births according to sex for Quebec were also obtained directly from the Centre d'information et de documentation of Institut de la Statistique du Québec (personal communication, Ms Brigitte Vaillancourt). These were analyzed for the period January 1994 to December 1996.

The data sources estimated a maximum of $2 \%$ error rates for various facets of both stillbirth and live birth data. However, this was not broken down into which variables trend towards this level of error and which have less inbuilt error. A $P$ value $\leq 0.05$ was taken to represent a statistically significant result.

\section{RESULTS}

\section{Annual Analysis, Quebec and Canada, Both Referendums}

In Quebec, there were 1958767 live births in total for the two study periods: 1975-1986 and 1990-2001. The total male birth count during this time period was 1007819 and the total female count was 950948 , giving an $\mathrm{M} / \mathrm{T}$ ratio of 0.515 .

In Canada during this time period, there were 8099600 live births in total. The total male birth count was 4159248 and the total female count was 3940 352, giving an M/T ratio of 0.514 . Results for the comparisons are shown in Tables 1 and 2 for Quebec and for Canada, respectively. 


\begin{tabular}{|c|c|c|c|c|c|}
\hline Year & $1975-1976$ & $1976-1977$ & $1977-1978$ & $1978-1979$ & $1979-1980$ \\
\hline Males & 51662 & 48086 & 49220 & 49462 & 50852 \\
\hline Females & 48033 & 45507 & 46254 & 46413 & 47503 \\
\hline Total & 99695 & 93593 & 95474 & 95875 & 98355 \\
\hline $\mathrm{UCI}$ & 0.52131 & 0.51698 & 0.51871 & 0.51907 & 0.52015 \\
\hline $\mathrm{M} / \mathrm{T}$ ratio & 0.51820 & 0.51378 & 0.51553 & 0.51590 & 0.51703 \\
\hline $\mathrm{LCl}$ & 0.51509 & 0.51057 & 0.51236 & 0.51273 & 0.51390 \\
\hline Year & $1981-1982$ & 1982-1983 & 1983-1984 & 1984-1985 & 1985-1986 \\
\hline Males & 48064 & 45502 & 45600 & 44819 & 43977 \\
\hline Females & 45276 & 43078 & 42572 & 42100 & 41607 \\
\hline Total & 93340 & 88580 & 88172 & 86919 & 85584 \\
\hline $\mathrm{UCI}$ & 0.51815 & 0.51698 & 0.52047 & 0.51897 & 0.51720 \\
\hline $\mathrm{M} / \mathrm{T}$ ratio & 0.51493 & 0.51368 & 0.51717 & 0.51564 & 0.51385 \\
\hline $\mathrm{LCl}$ & 0.51172 & 0.51038 & 0.51387 & 0.51231 & 0.51049 \\
\hline Year & 1990-1991 & 1991-1992 & 1992-1993 & 1993-1994 & 1994-1995 \\
\hline Males & 50528 & 50163 & 48324 & 46910 & 45542 \\
\hline Females & 47663 & 47541 & 45426 & 44393 & 43550 \\
\hline Total & 98191 & 97704 & 93750 & 91303 & 89092 \\
\hline $\mathrm{UCI}$ & 0.51772 & 0.51656 & 0.51866 & 0.51703 & 0.51447 \\
\hline $\mathrm{M} / \mathrm{T}$ ratio & 0.51459 & 0.51342 & 0.51546 & 0.51378 & 0.51118 \\
\hline $\mathrm{LCl}$ & 0.51146 & 0.51028 & 0.51225 & 0.51054 & 0.50789 \\
\hline Year & $1996-1997$ & 1997-1998 & 1998-1999 & 1999-2000 & 2000-2001 \\
\hline Males & 42767 & 39726 & 37918 & 38072 & 36946 \\
\hline Females & 40147 & 37669 & 36374 & 35828 & 34879 \\
\hline Total & 82914 & 77395 & 74292 & 73900 & 71825 \\
\hline $\mathrm{UCI}$ & 0.51921 & 0.51682 & 0.51399 & 0.51879 & 0.51805 \\
\hline $\mathrm{M} / \mathrm{T}$ ratio & 0.51580 & 0.51329 & 0.51039 & 0.51518 & 0.51439 \\
\hline \multirow[t]{2}{*}{$\mathrm{LCl}$} & 0.51239 & 0.50976 & 0.50679 & 0.51157 & 0.51073 \\
\hline & Pre+post & $1980-1981$ & Pre+post & 1995-1996 & \\
\hline Males & 477244 & 49760 & 436896 & 43919 & \\
\hline Females & 448343 & 46965 & 413470 & 42170 & \\
\hline Total & 925587 & 96725 & 850366 & 86089 & \\
\hline $\mathrm{UCI}$ & 0.51663 & 0.51760 & 0.51484 & 0.51350 & \\
\hline $\mathrm{M} / \mathrm{T}$ ratio & 0.51561 & 0.51445 & 0.51377 & 0.51016 & \\
\hline $\mathrm{LCl}$ & 0.51459 & 0.51129 & 0.51271 & 0.50681 & \\
\hline$x^{2}$ & Pre+post vs. & 0.48 & Pre+post vs. & 4.09 & \\
\hline$P$ & 1980-1981 & 0.49 & 1995-1996 & 0.04 & \\
\hline
\end{tabular}




\begin{tabular}{|c|c|c|c|c|c|}
\hline Year & 1975-1976 & 1976-1977 & 1977-1978 & 1978-1979 & 1979-1980 \\
\hline Males & 187469 & 183394 & 184812 & 186302 & 188839 \\
\hline Females & 176809 & 174456 & 174981 & 176130 & 178447 \\
\hline Total & 364278 & 357850 & 359793 & 362432 & 367286 \\
\hline $\mathrm{UCl}$ & 0.51626 & 0.51413 & 0.51530 & 0.51566 & 0.51576 \\
\hline $\mathrm{M} / \mathrm{T}$ ratio & 0.51463 & 0.51249 & 0.51366 & 0.51403 & 0.51415 \\
\hline $\mathrm{LCl}$ & 0.51301 & 0.51085 & 0.51203 & 0.51240 & 0.51253 \\
\hline Year & 1981-1982 & 1982-1983 & 1983-1984 & 1984-1985 & 1985-1986 \\
\hline Males & 190816 & 192321 & 192053 & 193742 & 192846 \\
\hline Females & 181656 & 181273 & 182480 & 182523 & 182535 \\
\hline Total & 372472 & 373594 & 374533 & 376265 & 375381 \\
\hline UCl & 0.51390 & 0.51639 & 0.51438 & 0.51651 & 0.51533 \\
\hline $\mathrm{M} / \mathrm{T}$ ratio & 0.51230 & 0.51479 & 0.51278 & 0.51491 & 0.51373 \\
\hline $\mathrm{LCl}$ & 0.51069 & 0.51318 & 0.51118 & 0.51331 & 0.51213 \\
\hline Year & 1990-1991 & 1991-1992 & 1992-1993 & 1993-1994 & 1994-1995 \\
\hline Males & 207004 & 206632 & 201613 & 198399 & 196326 \\
\hline Females & 195925 & 196475 & 190568 & 187760 & 185672 \\
\hline Total & 402929 & 403107 & 392181 & 386159 & 381998 \\
\hline $\mathrm{UCl}$ & 0.51529 & 0.51414 & 0.51565 & 0.51535 & 0.51553 \\
\hline $\mathrm{M} / \mathrm{T}$ ratio & 0.51375 & 0.51260 & 0.51408 & 0.51378 & 0.51395 \\
\hline $\mathrm{LCl}$ & 0.51220 & 0.51105 & 0.51252 & 0.51220 & 0.51236 \\
\hline Year & 1996-1997 & 1997-1998 & 1998-1999 & 1999-2000 & 2000-2001 \\
\hline Males & 184259 & 176597 & 173349 & 172823 & 168050 \\
\hline Females & 173054 & 168526 & 164946 & 164089 & 159057 \\
\hline Total & 357313 & 345123 & 338295 & 336912 & 327107 \\
\hline $\mathrm{UCl}$ & 0.51732 & 0.51336 & 0.51411 & 0.51465 & 0.51546 \\
\hline $\mathrm{M} / \mathrm{T}$ ratio & 0.51568 & 0.51169 & 0.51242 & 0.51296 & 0.51375 \\
\hline \multirow[t]{2}{*}{$\mathrm{LCl}$} & 0.51404 & 0.51002 & 0.51073 & 0.51127 & 0.51203 \\
\hline & Pre+post & 1980-1981 & Pre+post & 1995-1996 & \\
\hline Males & 1892594 & 190905 & 1885052 & 190697 & \\
\hline Females & 1791290 & 181234 & 1786072 & 181756 & \\
\hline Total & 3683884 & 372139 & 3671124 & 372453 & \\
\hline $\mathrm{UCl}$ & 0.51426 & 0.51460 & 0.51399 & 0.51361 & \\
\hline $\mathrm{M} / \mathrm{T}$ ratio & 0.51375 & 0.51299 & 0.51348 & 0.51200 & \\
\hline $\mathrm{LCl}$ & 0.51324 & 0.51139 & 0.51297 & 0.51040 & \\
\hline$x^{2}$ & Pre+post vs. & 0.77 & Pre+post vs. & 2.96 & \\
\hline$P$ & 1980-1981 & 0.38 & 1995-1996 & 0.09 & \\
\hline
\end{tabular}


In Quebec, the $\mathrm{M} / \mathrm{T}$ ratio was lower in the two referendum years than in the preceding and following five-year periods, but this dip was only statistically significant for the second referendum $(P=0.04)$. No significant dips were present for Canada for the same periods (Table 2).

\section{Monthly Analysis, Quebec, 1995 Referendum}

In January 1996, three months after the referendum, the $\mathrm{M} / \mathrm{T}$ ratio was 0.517 (95\% CI 0.505 to 0.525$)$, and it then fell steadily to May 1996, when the M/T ratio was 0.502 (95\% CI 0.491 to 0.513 ). The $\mathrm{M} / \mathrm{T}$ ratio then recovered rapidly as depicted in Figure 1. The $\mathrm{M} / \mathrm{T}$ ratios for three relevant time periods between January 1994 and December 1996 are shown in Figure 2. The initial decrease and the following increase were statistically significant (Table 3).

\section{Stillbirths}

There were no changes in annual numbers of stillbirths, which declined throughout the period studied (Figure 3).

\section{DISCUSSION}

The 1980 referendum on sovereignty in Quebec was based on the populace's acceptance of an agreement which would entitle Quebec to full sovereignty, with the ability to enact its own laws, levy taxes, and establish foreign relations. However, it was proposed that a common Canadian currency would (at least initially) be retained. The electorate was just over 4.3 million, and the voter turnout was $85.6 \%$. The "no" vote won by $59.6 \%$ against $40.0 \%$ in favour. ${ }^{17}$

The second referendum in 1995 was more closely run. The electorate had grown to just over five million; voter turnout increased to $93.5 \%$, and the "no" vote won by just $50.7 \%$ against $49.3 \%$ in favour. ${ }^{12}$

Stress is known to reduce the $\mathrm{M} / \mathrm{T}$ ratio. This is in accordance with the Trivers-Willard hypothesis ${ }^{18}$ which proposes that under favourable environmental conditions, more males are produced and when conditions are poorer, fewer males are produced. This is because under favourable circumstances, males have more reproductive opportunities than females, who are limited by a lengthy gestational period and a period of breastfeeding, which may reduce fertility. On the other hand, under poor circumstances, pregnant women tend to spontaneously abort male fetuses more often than female fetuses because males exert a higher metabolic demand on the mother ${ }^{19}$ and may be born frail. Such males may not survive to reproductive age, and, if frail, will not be able to compete with more robust males for mating privileges. Female babies are stronger and likelier than males to survive; if
Figure 1. Quarterly M/T ratio for Quebec, 1995 and 1996

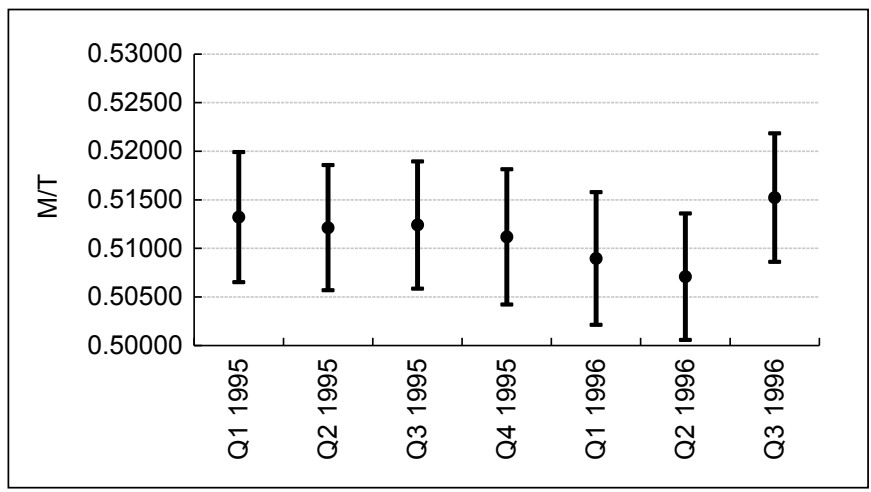

Figure 2. M/T ratio for Quebec, January 1994 to December 1995, January 1996 to May 1996, and June 1996 to December 1996

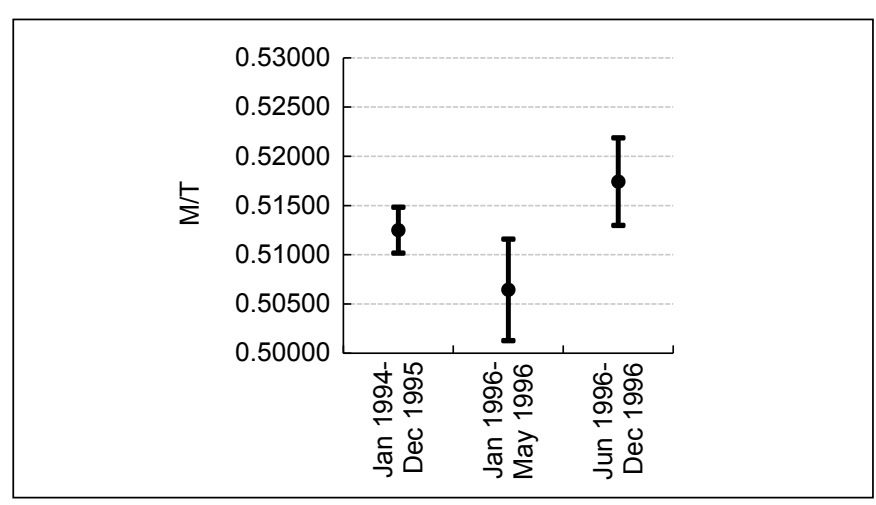

Figure 3. Annual stillbirths for the time period before and after the second referendum

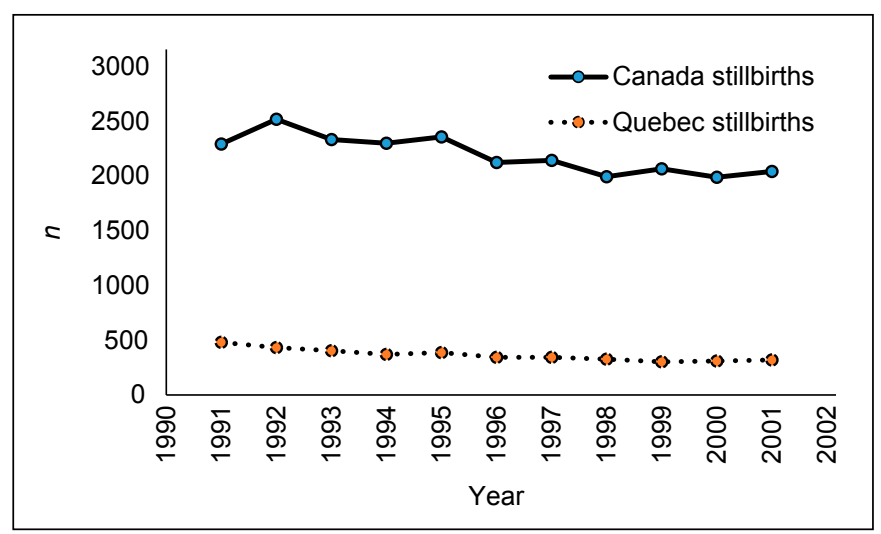




\begin{tabular}{|c|c|c|c|}
\hline \multicolumn{4}{|c|}{$\begin{array}{l}\text { Table 3. M/T ratio for Quebec, January } 1994 \text { to December 1995, January } 1996 \text { to } \\
\text { May 1996, and June } 1996 \text { to December } 1996 \text { with chi-tests for differences }\end{array}$} \\
\hline & $\begin{array}{l}\text { January } 1994 \text { to } \\
\text { December } 1995\end{array}$ & $\begin{array}{c}\text { January } 1996 \\
\text { to May } 1996\end{array}$ & $\begin{array}{l}\text { June } 1996 \text { to } \\
\text { December } 1996\end{array}$ \\
\hline M & 91058 & 18337 & 25314 \\
\hline $\mathrm{F}$ & 86617 & 17871 & 23608 \\
\hline $\mathrm{T}$ & 177675 & 36208 & 48922 \\
\hline $\mathrm{UCl}$ & 0.51482 & 0.51160 & 0.52187 \\
\hline $\mathrm{M} / \mathrm{T}$ ratio & 0.51250 & 0.50644 & 0.51744 \\
\hline \multirow[t]{2}{*}{$\mathrm{LCl}$} & 0.51017 & 0.50127 & 0.51300 \\
\hline & & $x^{2}$ & $p$ \\
\hline \multicolumn{2}{|c|}{$\begin{array}{l}\text { January } 1994 \text { to December } 1995 \text { vs. } \\
\text { January } 1996 \text { to May } 1996\end{array}$} & 4.42 & 0.035 \\
\hline \multicolumn{2}{|c|}{$\begin{array}{l}\text { January } 1996 \text { to May } 1996 \text { vs. } \\
\text { June } 1996 \text { to December } 1996\end{array}$} & 10.08 & 0.001 \\
\hline
\end{tabular}

they reach reproductive age, they are likelier to reproduce and pass on their parental genes. Hence, according to this hypothesis, natural selection has favoured mothers who are able to influence the sex of their offspring. ${ }^{18}$

Specific and related examples of the hypothesis include the rapid drop in the $\mathrm{M} / \mathrm{T}$ ratio in New York City three months after the terrorist attacks of September 11, 2001. This change in the $\mathrm{M} / \mathrm{T}$ ratio implies fetal loss and not biased rates of conceiving females, which would have skewed the $\mathrm{M} / \mathrm{T}$ ratio seven to nine months later. ${ }^{6}$ Another example was the sharp fall in the male birth rate in East Germany in 1991, the year after the reunification of Germany. ${ }^{20}$ That year was associated with an economic collapse in East Germany, including an unemployment rate of $20 \%$ and another $20 \%$ of workers working reduced days. ${ }^{20}$

It has also been shown in Japan that a sustained and prolonged decline in the $\mathrm{M} / \mathrm{T}$ ratio commenced in 1975 , one year after an economic contraction that has continued into this century. ${ }^{21}$ Sharp dips have also been witnessed in response to legislation enacted for political motives. For example, in Cuba the $\mathrm{M} / \mathrm{T}$ ratio dipped sharply in 1966, 1980, and 1985; all of these were associated with the passage of laws in the United States that facilitated entry of Cuban refugees into the United States. ${ }^{10}$

Falls in the M/T ratio have also been shown to occur in association with non-violent political events in noncontracting economies. In Malta, parliamentary elections evoked a change in the $\mathrm{M} / \mathrm{T}$ ratio similar to that illustrated in Quebec. Maltese parliamentary elections are hotly contested and narrowly won, and these appear to have caused changes in the $\mathrm{M} / \mathrm{T}$ ratio. ${ }^{11}$ In Malta, significant stress is driven by the bipartisan nature of the local political scene, which has produced intense political polarization of most of Maltese society. ${ }^{22}$

It can be argued that the situation is similar in Quebec, where the $\mathrm{M} / \mathrm{T}$ ratio fell in association with two referendums that proposed sovereignty. Before these referendums, the possibility that the province would secede from Canada had been a constant threat for decades, with numerous political, social and economic implications. The 1995 referendum appears to have generated a significant amount of anxiety: pre-voting opinion polls indicated that there was a very real possibility that Quebec would choose sovereignty, and in response over 150000 Québecoise demonstrated their support for continuing national unity by holding a public rally in downtown Montreal three days before the referendum. This extraordinary event was seen by many political experts as one of the key factors that narrowly turned the vote in favour of rejecting sovereignty, leading to a tense situation of "high drama." ${ }^{23,24}$ The M/T ratio fell three months after the referendum, beginning in January 1996 and continuing to May. It then recovered rapidly.

These events naturally generated significant stress in the Quebec population. ${ }^{25,26}$ Stress may have led to a fall in the $\mathrm{M} / \mathrm{T}$ ratio in similar fashion to the fall in New York three months after the terrorist attacks of September 11. However, this was not reflected by a change in stillbirth data, which are not available by sex.

The strengths of this study are the relative completeness of the data, the low level of error acknowledged by the data sources, and the large numbers available for analysis. 
The last of these particularly adds to the strength of the study because large numbers add greater statistical power to the data analysis. The limitations of the study are the unavailability of data on a monthly or quarterly basis for the first referendum, since more detailed analysis may possibly have shown an effect on the $\mathrm{M} / \mathrm{T}$ ratio using these more detailed data. Another limitation is the unavailability of data on premature delivery and on stillbirth data by sex.

Overall, these findings support the Trivers-Willard hypothesis. This is the first time that a political event has been shown to influence the $\mathrm{M} / \mathrm{T}$ ratio in Canada.

\section{ACKNOWLEDGEMENTS}

The author wishes to thank Brigitte Vaillancourt, Centre d'information et de documentation, Institut de la Statistique du Québec, and Vincent Rodrigue, Statistical Information Service, Statistics Canada, for assistance with data retrieval.

\section{REFERENCES}

1. James WH. The human sex ratio. Part 1: a review of the literature. Hum Biol 1987;59:721-52.

2. James WH. The human sex ratio. Part 2: a hypothesis and a program of research. Hum Biol 1987;59:873-900.

3. Song S. Does famine influence sex ratio at birth? Evidence from the 1959-1961 Great Leap Forward Famine in China. Proc Biol Sci 2012;279:2883-90.

4. Lyster WR. Altered sex ratio after the London smog of 1952 and the Brisbane flood of 1965. J Obstet Gynaecol Br Commonw 1974;81:626-31.

5. Zorn B, Sucur V, Stare J, Meden-Vrtovec H. Decline in sex ratio at birth after 10-day war in Slovenia: brief communication. Hum Reprod 2002;17:3173-7.

6. Catalano R, Bruckner T, Marks AR, Eskenazi B. Exogenous shocks to the human sex ratio: the case of September 11, 2001 in New York City. Hum Reprod 2006;21:3127-31.

7. Bruckner TA, Catalano R, Ahern J. Male fetal loss in the U.S. following the terrorist attacks of September 11, 2001. BMC Public Health 2010;10:273.

8. Masukume G. Live births resulting from advanced abdominal extrauterine pregnancy, a review of cases reported from 2008 to 2013. WebmedCentral Obstet Gynecol 2014;5:WMC004510.
9. Catalano R, Bruckner T, Gould J, Eskenazi B, Anderson E. Sex ratios in California following the terrorist attacks of September 11, 2001. Hum Reprod 2005;20:1221-7.

10. Grech V. The influence of migration on secular trends in sex ratios at birth in Cuba in the past fifty years. West Indian Med J 2014;63:372-6.

11. Grech V. The male:female ratio at birth is depressed by Maltese parliamentary elections and increased by other non-electoral events. Int J Tropical Dis Health 2014;4:1123-31.

12. Pammett JH, LeDuc L. Sovereignty, leadership and voting in the Quebec referendums Electoral Studies. Ottawa (ON): 2001;20:265-80. Statistics Canada. Available at: http://www5.statcan.gc.ca/cansim/a26?lan $\mathrm{g}=$ eng\&retrLang=eng\&id $=1024502 \&$ pattern $=$ births\&tabMode $=$ dataTable\&srchLan=-1\&p1=1\&p2=49. Accessed February 27, 2015.

13. Fleiss JL. Statistical methods for rates and proportions. 2nd ed. New York (NY): John Wiley and Sons; 1981:14-5.

14. Slezák P. Microsoft Excel add-in for the statistical analysis of contingency tables. Int J Innovation Educ Res 2014;2:90-100.

15. Gini C. Sulla probabilita che termini di una serie erratica sieno tutti crescenti (o non decrescenti) ovvero tutti decrescenti (o non crescenti) con applicazioni ai rapporti dei sessi nascite umane in intervalli successivi e alle disposizioni dei sessi nelle fratellanze umane. Metron 1955;17:1-41.

16. Fitzmaurice J, Morin JI. Quebec and Canada: past, present and future. New York (NY): St. Martin's Press; 1985.

17. Trivers RL, Willard DE. Natural selection of parental ability to vary the sex ratio of offspring. Science 1973;179:90-2.

18. Forchhammer MC. Timing of foetal growth spurts can explain sex ratio variation in polygynous mammals. Ecol Lett 2000;3:1-4.

19. Catalano RA. Sex ratios in the two Germanies: a test of the economic stress hypothesis. Hum Reprod 2003;18:1972-5.

20. Neumann M. German unification: Economic problems and consequences. Carnegie-Rochester Conference Series on Public Policy. 1992;36:163-209.

21. Grech V. The Japanese decline in secondary sex ratio correlates with percentage change in GDP/annum. Int J Tropical Dis Health 2015;5:130-5.

22. Baldacchino G. A nationless state? Malta, national identity and the EU. West European Politics 2002;25:191-206.

23. Evans JAS. The present state of Canada. Contemporary Rev 1996;269:125-34.

24. Clarke HD, Kornberg A. Choosing Canada? The 1995 Quebec sovereignty referendum. Pol Sci Politics 1996;29:676-82.

25. Flett GL, Endler NS, Fairlie P. The interaction model of anxiety and the threat of Quebec's separation from Canada. J Pers Soc Psychol 1999;76:143-50.

26. Nadeau R, Martin P, Blais A. Attitude towards risk-taking and individual choice in the Quebec referendum on sovereignty. Br J Political Science 1999;29:523-9. 